\title{
BORSÓSZEMEK A FALRÓL
}

\author{
TÓTH JÁNOS
}

„Ezért indítani kívánunk egy nyelvi rovatot." [11]

Szakszövegek helyesírásának, szóhasználatának és mondatszerkezeteinek néhány gyakori problémáját tárgyaljuk. Kitérünk a matematikai dolgozatoknál felmerülő különleges kérdésekre is.

\section{Bevezetés}

A jelen folyóirat egy korábbi számában Vizvári Béla korábbi felelős szerkesztő felkérte az olvasókat, hogy (szak)nyelvi megjegyzéseikkel is járuljanak hozzá a lap színvonalának emeléséhez. Sőt: lásd a mottót. A mostani alkalmat arra szeretném használni, hogy kérésének eleget téve, 70. születésnapja alkalmából (de a 73.-at le nem késve... ) megnyissam a rovatot.

A helyzetem azért nem könnyü, mert egyszerre vagyok a toleranciabajnok Nádasdy Ádám (lásd például [8]) lelkes híve, valamint türelmetlen szabálykövető és -követelő. Virágozzék tehát minden virág, de néhány gyom gyérítéséhez azért hadd járuljak hozzá.

\section{Helyesírás}

\subsection{Egybe- és különírás}

De, megtanulhatók.

Tudniillik a többszörös összetételek egybe- és különírásának szabályai [7, 139-141.] olyan részletességgel, ami a tipikus felhasználónak elegendő. A két szóból álló és a több szóból álló, de legfeljebb hatszótagú kifejezéseket egybe írjuk, többit kiskötőjellel: sürüségfüggvény (öt szótag), tüzoltólaktanya (három szó, de csak hat szótag), csapatzászló-avatás (három szó, de hét szótag). Néhány számunkra is érdekes kivétel: akasztófáravaló, pénzügyminisztérium, valószínüségszámítás. 
Tipikus anglicizmus a következő: általánosított inverz fogalom. Ha az egybeírás szabályait akarjuk követni, akkor általánosítottinverz-fogalom. De leginkább így írnám: az általánosított inverz fogalma.

Az idézőjelek elhelyezéséről a $\mathrm{TEX}_{\mathrm{E}}$ ([13]) képes gondoskodni, ha nem akadályozzuk meg ebben. Mára sajnos beszédben is elterjedt az angolszász szokásnak megfelelő "idézés", tehát sokszor látjuk azt, hogy a beszélő kezével kétszer is a fölső állásban hadonászik, pedig először alsóban, másodszor fölsőben kellene kalimpálnia.

\subsection{Vízszintes pálcikák}

Írástudó, vagyis $\mathrm{T}_{\mathrm{EX}} \mathrm{X}$-ben és $\mathrm{AT}_{\mathrm{EX}} \mathrm{X}$-ben járatos hallgatóimnak el szoktam árulni, hogy a Cauchy-sorozat kiskötőjellel írandó, a tól-ig szerkezetekben viszont (lásd [7, 264. és 178.]), amilyen például a 10-12 oldal, 3-4 ember, és a kezdő és záró oldalszám közé az irodalomjegyzékben két pálcika egymás mellé írásával kapjuk a nagykötőjelet. Figyeljük meg az alábbi kifejezés írásmódját is: Cauchy-Schwarz-Csebisev-Bunyakovszkij-egyenlőtlenség. Mi még így tanultuk; nem végeztem elmélyült, önálló matematikatörténeti kutatásokat annak eldöntésére, hogy kinek mekkora szerepe volt a tételben, de megnéztem a Besenyei Ádám (http://www.ematlap.hu/index.php/ konyvespolc-2017-03/451-konyveket-ajanlunk-honlapokat-ajanlunk) által ajánlott honlapot: http://jeff560.tripod.com/c.html. Eszerint az egyenlötlenség különféle formáit használta Cauchy 1821-ben, Schwarz szerint pedig Bunyakovszkij 1859-ben. Poincaré 1859-ben Schwarzról, Hardy és Littlewood 1920-ban Cauchyról és Schwarzról nevezte el az egyenlőtlenséget.

Feltünhetett az olvasónak, hogy fentebb a kiskötőjel és nagykötőjel szavakat egybeírtam: ezek nem kicsi vagy óriási kötőjelek, hanem őket az egybeírt kifejezés azonosítja. Hasonló ezekhez a kis- és nagybetü: a kisbetű is lehet akár 24 pontos.

\subsection{Lázadás}

Itt néhány rebellis gondolatomat említem meg. Következetesen („gondozott szöveg") ezt írom: október 10.-én, és nem október 10-én, mert az utóbbi szabályosnak deklarált [7, 295. és 298.] formát én nem tudom másképpen olvasni, mint így: október tízén. Olvassák ki ezeket is („fonetikus” a magyar...): 1-i, 1-ji, 1-jei, 10-e óta. Szerintem legalábbis mókásan hangzanak.

Az ábécésorrenddel kapcsolatban azt még lenyelném, hogy az o és az ó betü között nem kell különbséget tenni [7, 14. c)], ha ugyanis az elsőt elég sokáig hangoztatjuk, akkor a másodikat kapjuk. Ugyanez az eljárás viszont nem jár a kívánt eredménnyel az $a$ és á betű esetén. E két betű azonosításának egyetlen eredménye, hogy a listák (telefonkönyv és társai) sokkal nehezebben kezelhetőek, mint ha tudomásul vennénk (ahogyan ezt például az EXCEL teszi, bár az ő sorrendje sem kielégítő teljesen), hogy itt nemcsak időtartamban van különbség a két betü kiejtése között, hanem a hangképzés módjában is. Megjegyzendő, hogy [7, 14. b)] 
utolsó bekezdése is rontja, míg [7, 14-16.] összes többi része segíti a tájékozódást a listákban. Reménykedjünk a szabályzat további kiadásaiban.

\section{Szóhasználat}

Stílusunk biztosan jobb lesz, ha elkerüljük a hivatali bikkfanyelv üres fordulatait: kerül, történik, biztosít, eszközöl, szolgáltat, lehetőség/mód van/nyílik rá, mentén, tekintetében, vonatkozásában, kimaxol stb. A sajnálatosan elterjedt használat mellett ezek a szavak a szövegből a legkisebb károsodás nélkül kiiktathatók. Sőt. Ennek a bekezdésnek az eleje éppen azt mutatja, hogy nem a szavak a bünösek, hanem az, aki lehetőséget kerít biztosításukra. Feladatul adjuk az olvasónak, hogy elemezze, melyik szörnyeteg kedvence a programozóknak, melyiket imádják a politikusok, és melyiket a jogászok vagy az internet népe.

Élvezetes példák vannak összegyüjtve itt is: [3, 236-240. oldal], valamint Nádasdy Mit utáljunk? címü írásában ([9, 274-278. oldal]). Ez utóbbiból idézek: „sorjáz, munkál és hajaz. Pfúj."

\section{Mondatszerkezet}

Kicsit szerencsésebb („magyarosabb”) az igei szerkezet a névszóinál, tehát tetszetősebb (nekem) ez: mókásan hangzanak, mint ez: mókás hangzásúak.

Meg kellene szabadulni attól a babonától, hogy a határozói igenév elátkozott: nem igaz, nincs elátkozva. Néha még arra is kedvem szottyan, hogy többes számba tegyem, de ezt nem vesszük be a javallatok közé. Hogy még két példát idézzek [3, 239. oldal] alapján: arra van egy kőhíd rakva és nem pedig arra egy kőhíd rakott. [9, 275. oldal]: „Az üzlet riasztóval védett. Förtelmes germanizmus.”

Arról (is) szól a történet, hogy ne használjunk közhelyeket.

\section{Matematikai specialitások}

Sokunk számára kiindulópont Halmos Pál cikke: [5]; az újszülötteknek melegen ajánlom. Egyetlen gondolatot idézek belőle, a többiekért forduljon az olvasó a forráshoz. [5, 279. oldal]: „a függvény és a függvény értéke közötti különbség nagyobb annál, semhogy figyelmen kívül hagyható lenne... ne mondjunk olyat, hogy a $z^{2}+1$ függvény páros. $\mathrm{Az} f(z)=z^{2}+1$ összefüggéssel értelmezett $f$ függvény páros... a $z \mapsto z^{2}+1$ függvény páros." (Sajnos, az angol eredetiben szereplő - helyes $-\mapsto$ jel a magyar szövegben így jelenik meg: $\rightarrow$.)

A fenti fogalmazás egy részét kicsit pontosítanám, így: „Az $f(z):=z^{2}+1$ összefüggéssel értelmezett $f$ függvény" forma kifejezi a definiáló egyenlöség aszimmetriáját, szemben a = szimmetrikus egyenlőségjellel, amely egy reláció jele, egy kétváltozós függvényé, amelynek értéke igaz vagy hamis. 
A téma fontossága miatt vegyünk még egy példát.

A $\varphi(x)=\frac{1}{\sqrt{2 \pi}} e^{-\frac{x^{2}}{2}}$ egyenlet a standard normális eloszlást írja le.

(Megkímélem a szerzőt attól, hogy megnevezzem.) Több, ettől az „állítás”-tól eltérö mondatnak is van értelme.

- $A \mathbb{R} \ni x \mapsto \varphi(x):=\frac{1}{\sqrt{2 \pi}} e^{-\frac{x^{2}}{2}}$ hozzárendeléssel értelmezett $\varphi$ függvényt a standard normális eloszlás sürüségfüggvényének nevezzük. Itt tehát definiáló egyenlőség segítségével bevezettük a bal oldalon álló rövid jelölést a jobb oldalon álló függvényre, és egyúttal nevet is adtunk neki.

- Valahonnan (mérési adatokból, fizikai levezetésből) megkaptuk a $\varphi$ függvényt, és megállapítjuk, hogy a $\varphi(x)=\frac{1}{\sqrt{2 \pi}} e^{-\frac{x^{2}}{2}}$ reláció minden $x \in \mathbb{R}$ esetén igaz értéket ad. (Pontosan így használja a Wolfram nyelv az Equal függvényt, míg az előző esetre a Set vagy a SetDelayed szolgál, mint az azonnali és a késleltetett értékadás realizációja a nyelvben.)

- Egy feladat megoldása közben eljuthatunk ahhoz a kérdéshez, hogy milyen $x$ valós számokra áll fenn a $0.1=\frac{1}{\sqrt{2 \pi}} e^{-\frac{x^{2}}{2}}$ egyenlet. Ez az egyenlet szó megfelelő használata. Itt valójában arról van szó, hogy az

$$
F:=\left(\mathbb{R} \ni x \mapsto 0.1=\frac{1}{\sqrt{2 \pi}} e^{-\frac{x^{2}}{2}}\right)
$$

hozzárendelés igazsághalmazát keressük, azaz azokat az $x$ számokat (a megoldásokat), amelyekre az $F$ függvény értéke igaz. Szokás az $F$ függvényt nyitott állításnak is nevezni [10, 93. oldal]. [4, 109. oldal] a kitöltetlen kifejezést használja.

- A pontok az $y=\varphi(x)$ egyenletü görbére esnek. Ezt a mondatot annak rövidítéseként foghatjuk fel, hogy a pontok részhalmazát képezik az

$$
\left\{(x, \varphi(x)) \in \mathbb{R}^{2}\right\}
$$

halmaznak.

További megjegyzések következnek.

- Miért szerepel 0.1 a fentiekben a magyar helyesírásnak megfelelő 0,1 helyett? Lehangoló élményem volt, amikor egy Rátz László Vándorgyủlésen egy szegény tanár megkérdezte a jelenlévő magas akadémikusoktól, hogy miért írjon ő vesszőt a tizedespont helyett, amikor például az állandóan kezünkben lévő számológépeken a gyerekek is tizedespontot látnak. Mintha a kérdés el se hangzott volna... Azóta viszont örömmel tapasztaljuk, hogy pl. az EXCEL magyarított változata is vesszőt használ, értelmetlenül tovább bonyolítva a helyzetet. (Ha valakinek ez érv: a II. világháború előtt pontot használtak, bár nem az alapvonalon, hanem a szám magasságának kétharmadában.) 
- Képlettel nem kezdünk mondatot. $f>0$ azt fejezi ki, hogy helyett inkább Az $f>0$ reláció azt fejezi ki, hogy.

- Képletet nem ragozunk. Ez utóbbi elkerülése végett használjuk Czách tanár úr nyomán a - néha már modorosnak tünő - jelölje $x$ fordulatot.

- Írásban nem szívesen használom a kéne szót, és darab helyett inkább számút mondok, a plusz feltétel nél jobb a további feltétel. (Vegyünk $n$ számú csúcspontot, vagy $n$ csúcspontot.)

- Szóban se szeretem, de sokan használják még írásban is az ilyen kifejezéseket: az $f$; én inkább azt mondom, hogy $f$, vagy azt, hogy az $f$ függvény.

- Mi a baj az alábbi definícióval?

5.1. Definíció. Az $f$ függvény folytonosan differenciálható, ha differenciálható, és derivált függvénye folytonos.

Az, hogy nem tesz eleget a pisztolyról szóló Csehov-axiómának. Miért vezetnénk be az $f$ jelet a függvényre, ha a továbbiakban nem használjuk?

- Annál, hogy legyenek $x$ és $y$ valós számok, jobban tetszik, hogy legyen $x$ és y valós szám, bár ha hátranézek, a polcomon Petőfi Sándor Összes müveit látom, de keresésem eredményeként a Google Mikszáth, József Attila és Márai Sándor Összes müvét kínálja. Magyar nyelvterületen a feleségeik szinte biztosan hibás, viszont ma már lehet helyes a felszólítás: Kapcsolják ki telefonjaikat!

- Egy $x$ szám abszolút értéke helyett jobb: az $x$ szám abszolút értéke.

- Ami az írásmü elején áll, az nem absztrakt, hanem kivonat magyarul. Nem licensz, hanem licenc, hisz ezt a szót nem a múlt héten vettük át az angolból.

- És még egy megjegyzés az írásművek végéről. Matematikusok képesek befejezni úgy egy cikket, hogy ezzel a 23. tétel be van bizonyítva, ahelyett, hogy arról elmélkedének kicsit még, hogy a deklarált (eseteg a címben is kihirdetett, csábos) célt sikerült-e elérniük, mi az, amit nem, miért nem: nem volt elég idő, számítógép-kapacitás, tudás, ötlet, borsó. Mi várható a jövőben? Mi az, amit megtudtunk? Mihez kapcsolódik a matematikán belül vagy kívül? (Nem az azonnali értékesítésre gondolok.) Merre megyünk tovább? 
Csak remélem, hogy a rovat további bővültével a nyelvi kérdésekről élénk vita fog kialakulni, amihez az ünnepelt is - eddigi szerkesztői munkáján túl, explicite is hozzájárul majd. És a legközelebbi kerek születésnapra talán ahhoz is veszem a bátorságot, hogy a matematikai kémia (az alkalmazott matematika egy fejezete) történetéről írjak [12] - már eddig is eredményesebb - felhívásának (lásd például $[1,2,6]$, nem beszélve a nekrológokról) eleget téve.

\section{Köszönetnyilvánítás}

A dolgozat részben az SNN 125739 számú NFKIH pályázat támogatásával készült.

\section{Hivatkozások}

[1] AрÁтну, M.S.: Az útvonaltervezö algoritmus történeti áttekintése, különös tekintettel azok turisztikai célú alkalmazásaira, Alkalmazott Matematikai Lapok, Vol. 33 No. 1, pp. 93-118 (2016).

[2] W. Cook: A kombinatorikus egészértékü programozás ötvenegynéhány éve, fordította: Bernáth Attila, Alkalmazott Matematikai Lapok, Vol. 30, pp. 23-80 (2013).

[3] Csermely, P., Gergely, P., Koltay, T. és Tóth, J.: Kutatás és közlés a természettudományokban, Osiris Kiadó, Budapest, (1999).

[4] G. Frege (Szerk. Ruzsa, I.): Logika, szemantika, matematika. Válogatott tanulmányok, Gondolat, Budapest, (1980).

[5] Halmos, P.R.: Hogyan írjunk matematikát? Matematikai Lapok, Vol. 26 No. 3/4, pp. 265-286 (1975).

[6] Komáromi, É.: Prékopa, András: Lineáris programozás I. - A magyar operációkutatás első félidejéről, ahogy én láttam, Alkalmazott Matematikai Lapok, Vol. 35, pp. 29-42 (2018).

[7] MTA: A magyar helyesírás szabályai, Akadémiai Kiadó, Budapest, tizenkettedik kiadás (2015).

[8] NÁDASDy, Á.: Ízlések és szabályok. Írások nyelvről, nyelvészetről, Magvető Kiadó, Budapest, (2003).

[9] NÁDASDy, Á.: Prédikál és szónokol. Magvető Kiadó, Budapest, (2008).

[10] VARGa, T.: Matematikai logika kezdőknek 2, Tankönyvkiadó, Budapest, (1966).

[11] Vizvári, B.: Nyelvészkedés, Alkalmazott Matematikai Lapok, Vol. 21 No. 1, p. 175 (2004).

[12] Vizvári, B.: Szakmánk története, Alkalmazott Matematikai Lapok, Vol. 26 No. 2, pp. 403-404 (2009).

[13] Wettl, F., Mayer, G. és Szabó, P.: LATEX kézikönyv. Panem Kiadó, Budapest, (2004). 


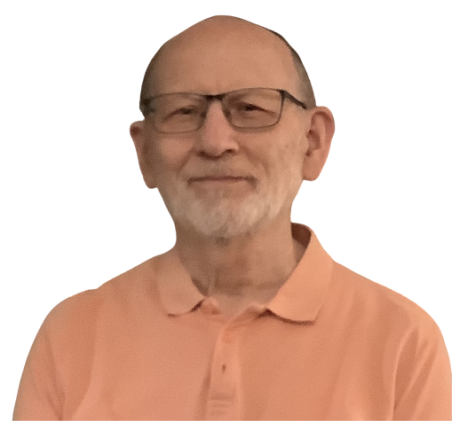

Tóth János (1947) az ELTE TTK matematikus szakán végzett. Kandidátusi értekezését 1986-ban védte meg a Magyar Tudományos Akadémián. 2010-ben habilitált matematikából a BME-n. Dolgozott a Semmelweis Orvostudományi Egyetemen, a Magyar Tudományos Akadémia Számítástechnikai és Automatizálási Kutató Intézetében, majd Müszaki Kémiai Kutató Intézetében. Vezette a Gödöllő Agrártudományi Egyetem Számítástechnikai Tanszékét, majd nyugdíjazásáig a BME Analízis Tanszékén oktatott, jelenleg ott címzetes egyetemi tanár. Az Eötvös Loránd Tudományegyetemen 1976-tól fogva néhány évtizeden keresztül tartott órákat.

1981-ben Farkas Gyula-díjat kapott, 2013-ban pedig elnyerte a Mathematics in (bio)Chemical Kinetics and Engineering életmüdíját.

Kutatási területe a formális reakciókinetika elmélete és alkalmazásai és a differenciálegyenletek kvalitatív elmélete. Két angol és több magyar könyve, 100 körüli folyóiratcikke jelent meg, összes hivatkozásainak száma a https://scholar . google.hu/citations?hl=hu\&user=_6V4DdoAAAAJ szerint 2000 fölött van.

Tagja az AMS-nek, a SIAM-nak, a Bolyai János Matematikai Társulat Ellenőrző Bizottságának elnöke, tagja a Magyar Égéstudományi Bizottságnak és a Magyar Tudományos Akadémia Reakciókinetikai és Fotokémiai Munkabizottságának, szerkesztője a Bolyai János Matematikai Társulat elektronikus folyóiratának, az Érintőnek: https://ematlap.hu.

\section{TÓTH JÁNOS}

BME Analízis Tanszék,

1111 Bp. Egry J. u. 1.

és ELTE Reakciókinetikai Laboratórium,

1117 Pázmány P. sétány 1/A.

jtoth@math.bme.hu

\section{WATER DROPS OFF A DUCK'S BACK}

JÁNOS TóTH

Following the announcement of the editor for 16 years, Béla Vizvári, we collected a few ideas about how to write or speak about mathematics.

Keywords: grammar, spelling, vocabulary of mathematical texts

Mathematics Subject Classification (2020): 00-02, 97-02, 00A99. 